\title{
SOSIALISASI MAKANAN DARURAT BENCANA BERBASIS SINGKONG DI DESA SUKARASA KECAMATAN SALAWU KABUPATEN TASIKMALAYA
}

\author{
HR Agus Bachtiar ${ }^{1}$ dan Ima Karimah ${ }^{2}$ \\ ${ }^{1,2}$ Jurusan Gizi Poltekkes Kemenkes Tasikmalaya \\ agusb6859@gamail.com
}

Diterima: 30 Oktober 2018 Direvisi: 01 November 2018 Diterbitkan: 07 Januari 2019

\begin{abstract}
Sukarasa Village is one of the villages in Salawu Subdistrict which is prone to land disasters. During a disaster, the community felt that food aid was often in the form of instant noodles. This makes the refugees bored with the food menu provided. In addition, if the food menu does not vary it can have an impact on health and nutrition conditions, especially in vulnerable groups. Thus, a training program for making Emergency Disaster food was carried out in Sukarasa Village, Salawu District, Tasikmalaya Regency. The methods of activities carried out included the Self-Observation Survey, Village Community Consultation, Product Testing, Emergency Disaster Food Making Training, Exhibition of Product Development Results, Preparation of Cassava Processed Food Guidelines, and Monitoring Evaluation. The target of this training activity is 9 cassava craftsmen. The products trained consisted of cassava noodles, kicimpring eel, and jerky cassava leaves. After the training activity, the product develops from 3 recipes to 20 recipes. The product consists of egg sponges, milkfish paste, crushed tilapia, kikimpring tuna, shrimp paste paste, kicimpring tempe, original rebon ring, kicimpring jengkol, and stirring spicy rebon. The jerky products of cassava leaves consist of beef jerky spicy cassava leaves, beef jerky sweet cassava leaves, jerky savory cassava leaves, beef jerky sweet spicy cassava leaves, pumpkin siam jerky, spinach jerky, banana heart jerky, katuk dendeng, katuk dendeng, jerky genjer, and kangkeng dendeng. Besides that, they also make cassava noodles.
\end{abstract}

Keywords: Training, emergency food, cassava

\begin{abstract}
ABSTRAK
Desa Sukarasa merupakan salah satu desa di Kecamatan Salawu yang rawan bencana pergeseran tanah. Pada saat kejadian bencana, masyarakat merasa bahwa bantuan pangan seringnya berbentuk mie instan. Hal ini membuat para pengungsi menjadi bosan dengan menu makanan yang diberikan. Selain itu, jika menu makanan tidak bervariasi dapat berdampak terhadap kondisi kesehatan dan gizi, terutama pada kelompok rentan. Sehingga, dilaksanakan kegiatan pelatihan pembuatan makanan Darurat Bencana di Desa Sukarasa, Kecamatan Salawu, Kabupaten Tasikmalaya. Metode kegiatan yang dilaksanakan diantaranya adalah Survey Mawas Diri, Musyawarah Masyarakat Desa, Uji Coba Produk, Pelatihan Pembuatan Makanan Darurat Bencana, Pameran Hasil Pengembangan Produk, Penyusunan Pedoman Makanan Olahan Singkong, dan Monitoring Evaluasi. Sasaran kegiatan pelatihan ini adalah 9 orang pengrajin singkong. Produk yang dilatihkan terdiri dari mie singkong, kicimpring belut, dan dendeng daun singkong. Setelah kegiatan pelatihan, produk berkembang dari 3 resep menjadi 20 resep. Produk tersebut terdiri kicimpring telur, kicimpring bandeng, kicimpring ikan nila, kicimpring ikan tongkol, kicimpring terasi udang, kicimpring tempe, kicimpring rebon original, kicimpring jengkol, dan kicimpring rebon pedas. Produk dendeng daun singkong terdiri dari dendeng daun singkong pedas, dendeng daun singkong manis, dendeng daun singkong gurih, dendeng daun singkong manis pedas, dendeng labu siam, dendeng bayam, dendeng jantung pisang, dendeng daun katuk, dendeng genjer, dan dendeng kangkung. Selain itu juga membuat mie singkong.
\end{abstract}

Kata kunci: Pelatihan, makanan darurat, singkong 


\section{PENDAHULUAN}

Kabupaten Tasikmalaya merupakan salah satu daerah di Jawa Barat yang termasuk rawan bencana. Berdasarkan informasi dari BNPB, Kabupaten Tasikmalaya merupakan daerah rawan bencana urutan ke-2 di Indonesia. Bencana juga berdampak terhadap kondisi kesehatan masyarakat. Bencana yang diikuti dengan pengungsian berpotensi menimbulkan masalah kesehatan yang sebenarnya diawali oleh masalah bidang/sektor lain. Timbulnya masalah kesehatan antara lain berawal dari kurangnya air bersih yang berakibat pada buruknya kebersihan diri, buruknya sanitasi lingkungan yang merupakan awal dari perkembangbiakan beberapa jenis penyakit menular ${ }^{1}$.

Persediaan pangan yang tidak mencukupi juga merupakan awal dari proses terjadinya penurunan derajat kesehatan yang dalam jangka panjang akan mempengaruhi secara langsung tingkat pemenuhan kebutuhan gizi korban bencana. Pengungsian tempat tinggal (shelter) yang ada sering tidak memenuhi syarat kesehatan sehingga secara langsung maupun tidak langsung dapat menurunkan daya tahan tubuh dan bila tidak segera ditanggulangi akan menimbulkan masalah di bidang kesehatan.

Desa Sukarasa merupakan salah satu desa di Kecamatan Salawu yang rawan bencana, terutama akibat pergeseran tanah. Di desa tersebut terdapat dua kampung yang cukup rentan yaitu Margahayu dan Babakan Sarongge. Salah satu kendala yang ada pada saat terjadi bencana di desa ini adalah terbatasnya bantuan pangan kepada para korban (Bapak Nanang). Masyarakat merasa bahwa bantuan pangan seringnya berbentuk mie instan. Hal ini membuat para pengungsi menjadi bosan dengan menu makanan yang diberikan relawan.

Hasil diskusi dengan aparat Desa Sukarasa, permasalahan mendasar pada saat terjadi bencana yaitu, terbatasnya bantuan pangan kepada para pengungsi. Sementara Desa Sukarasa khususnya Dusun Babakan Sarongge memiliki potensi produksi singkong yang melimpah. Namun, pemanfaatan singkongnya masih terbatas. Sebagian besar warga Babakan Sarongge mengolah singkong menjadi makanan tradisional seperti kicimpring, papais singkong, singkong rebus, singkong bakar,dan urab singkong.

Berdasarkan hal tersebut, maka untuk mengurangi permasalahan tersebut dilaksanakan Pelatihan Makanan Darurat Berbasis Singkong di Desa Sukarasa Kecamatan Salawu Kabupaten Tasikmalaya. Kegiatan bertujuan untuk melatih keterampilan masyarakat dalam membuat makanan darurat berbasis pangan lokal setempat, khususnya singkong. Diharapkan dengan adanya kegiatan pelatihan ini masyarakat mampu menyediakan makanan darurat pada saat kejadian bencana dengan memanfaatkan singkong sebagai pangan lokal daerah setempat.

\section{METODE}

Kegiatan ini berlangsung dari bulan Februari sampai Oktober 2018. Kegiatan ini dilaksanakan di Dusun Babakan Sarongge, Desa Sukarasa, Kecamatan Salawu, Kabupaten Tasikmalaya. Pemilihan lokasi ini dilakukan secara purposive dengan dasar pertimbangan bahwa daerah tersebut merupakan salah satu desa rawan bencana.

Sasaran kegiatan ini adalah masyarakat Dusun Babakan Sarongge, Desa Sukarasa, Kecamatan Salawu, yang terdiri dari kelompok ibu-ibu yang pernah membantu menyiapkan makanan pada saat bencana pergeseran tanah di Desa Sukarasa. Metode pengabdian kepada masyarakat yang dilaksanakan meliputi:

\section{a. Survey Mawas Diri}

Kegiatan ini bertujuan untuk mengidentifikasi permasalahan mitra. Kegiatan ini terdiri dari:

- Diskusi dengan aparat desa, petugas BPBD Kabupaten Tasikmalaya, dan tokoh masyarakat.

- Observasi lapangan dengan berkeliling melihat lokasi rawan bencana dan melihat potensi lokal yang ada di Dusun Babakan Sarongge, Desa Sukarasa, Kecamatan Salawu, Kabupaten Tasikmalaya.

- Analisis data sekunder tentang kesehatan dan gizi yang ada di Dusun Babakan Sarongge, Desa Sukarasa, Kecamatan Salawu, Kabupaten Tasikmalaya. 


\section{b. Musyawarah Masyarakat Desa}

Kegiatan ini berupa FGD dengan pihak terkait membahas permasalahan yang ditemukan pada saat kejadian bencana dan solusi yang ditawarkan terhadap permasalahan yang ditemukan. Peserta yang akan dilibatkan diantaranya aparat desa, tokoh masyarakat, Tim PKK, Tim Karang Taruna, Ibu Hamil, Ibu Menyusui, Lansia, Kader Posyandu, Kader Posbindu. Selain itu, dibentuk tim dapur umum tanggap darurat bencana.Tim ini yang nantinya akan mengikuti kegiatan pelatihan penyusunan buku pedoman makanan darurat.

\section{c. Uji Coba Produk}

Kegiatan ini merupakan kegiatan uji coba pengolahan pangan lokal yang ada untuk mendapatkan contoh makanan yang akan dilatihkan dan dikembangkan. Kegiatan ini dilaksanakan di Laboratorium Kulinari Gizi Poltekkes Kemenkes Tasikmalaya.

\section{d. Pelatihan Pembuatan Makanan Darurat Bencana}

Kegiatan pelatihan ini ditujukkan kepada tim dapur umum di Desa Sukarasa. Makanan yang dilatihkan difokuskan pada makanan kudapan berbahan baku singkong yaitu Mie Singkong, Kicimpring Singkong, dan Dendeng Daun Singkong.

Setelah itu, peserta dibagi 2 kelompok dan diberi modal Rp 250.000,- untuk membuat pengembangan atau berinovasi minimal 3 resep makanan dari materi yang telah dilatihkan.

\section{e. Pameran Hasil Pengembangan Produk}

Pada kegiatan ini disampaikan makanan olahan berbasis singkong yang telah disusun dan dilombakan. Kegiatan ini dilakukan oleh tim dapur umum dan dihadiri oleh aparatur desa.

\section{f. Penyusunan Pedoman Makanan Olahan Singkong}

Kegiatan ini dilakukan oleh tim dapur umum, menyesuaikan dengan potensi lokal dan kebiasaan masyarakat sekitar berupa makanan olahan berbasis singkong yang sudah dilombakan dan dipamerkan. Tim dari Poltekkes berperan sebagai fasilitator dan editor pembuatan pedoman.

\section{g. Monitoring dan Evaluasi}

Monitoring dilakukan untuk mengetahui perkembangan pembuatan produk olahan dari singkong dan penjualannya. Kegiatan dilakukan dengan kunjungan kepada kelompok tim inti dapur umum di Dusun Babakan Sarongge, Desa Sukarasa, Kecamatan Salawu, Kabupaten Tasikmalaya.

\section{HASIL DAN PEMBAHASAN}

\section{Survey Mawas Diri}

Pada kegiatan ini kami bertemu dengan kepala Desa Sukarasa dan diajak berkeliling lokasi pergeseran tanah di masyarakat. Sebelum melihat lokasi kejadian kami berdiskusi terlebih dahulu mengenai sasaran dalam kegiatan kami. Hasil diskusi menunjukkan bahwa terdapat dua daerah yang menjadi fokus sasaran kami, yaitu Kampung Babakan Sarongge dan Kampung Margahayu. Hasil lainnya dari diskusi kami adalah menentukan tanggal kegiatan musyawarah masyarakat desa dan pesertanya.

\section{Musyawarah Masyarakat Desa}

Kegiatan MMD dilaksanakan pada tanggal 31 Juli 2018, yang bertempat di Balai Desa Sukarasa. Pada kegiatan ini disampaikan mengenai tujuan kegiatan pengabmas serta jenis kegiatan yang akan dilaksanakan. Selain itu, kami mendengarkan masukan dari masyarakat maupun aparat yang hadir, serta penentuan waktu pelaksanakan kegiatan dan peserta pelatihan. Salah satu pesan dari masyarakat mengenai pangan bantuan kepada korban adalah menu yang kurang bervariasi. Mereka merasa antusias ketika akan diadakannya pelatihan ini. Peserta pelatihan yang diusulkan sebanyak 9 orang. Peserta yang terlibat ini adalah ibu-ibu yang terlibat di dapur umum pada saat terjadi bencana pergeseran tanah.

\section{Uji Coba Produk}

Kegiatan uji coba makanan hasil olahan singkong dilaksanakan di Laboratorium Kulinari Gizi Poltekkes Kemenkes Tasikmalaya. Makanan yang dibuat diantaranya adalah mie dari tepung 
singkong dan kicimpring. Dendeng tidak dipraktekan karena pernah dilakukan pada proses perkuliahan, yaitu mata kuliah kuliner pangan lokal.

\section{Pelatihan Pembuatan Makanan Darurat Bencana}

Kegiatan ini dilaksanakan pada hari Selasa tanggal 14 Agustus 2018, bertempat di salah satu rumah warga. Kegiatan ini dibantu oleh mahasiswa. Mahasiswa berperan sebagai fasilitator dalam pembuatan makanan tersebut. Peserta pelatihan penyusunan menu ini melebihi target yang direncanakan, yaitu 9 orang. Target awal peserta adalah 6 orang. Hal ini dikarenakan masyarakat sangat antusias dengan program ini. Mereka ingin sekali mendapatkan pengetahuan mengenai pengolahan makanan berbasis singkong.

Proses pelatihan berjalan dengan lancar. Para peserta sangat antusias dengan kegiatan ini, hal ini dapat dilihat dari partisipasi dalam membuat mie, kicimpring maupun dendeng. Semua ingin mencoba membuat, saling bergantian.

\section{CARA MEMBUAT MIE SINGKONG}

Campurkan telur, tepung singkong, tepung terigu cakra, minyak, nutri jel dan bumbu

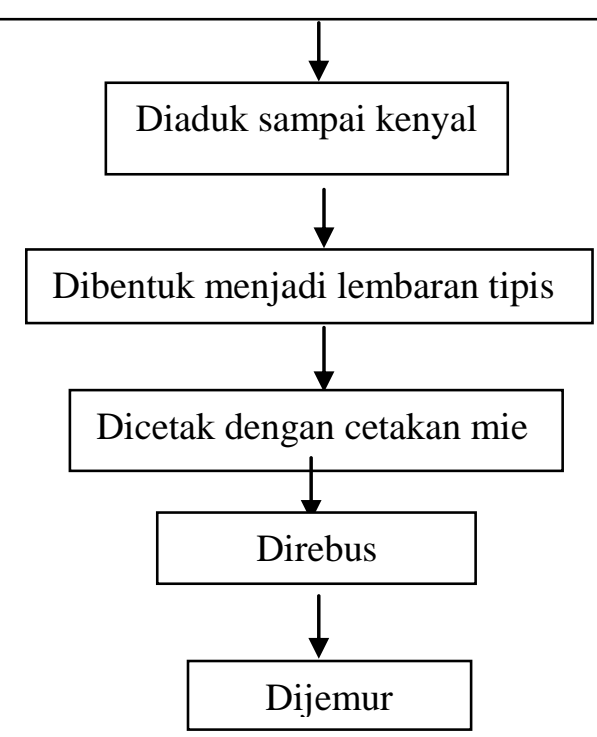

Gambar 1 Cara membuat mie singkong

\section{CARA MEMBUAT KICIMPRING}

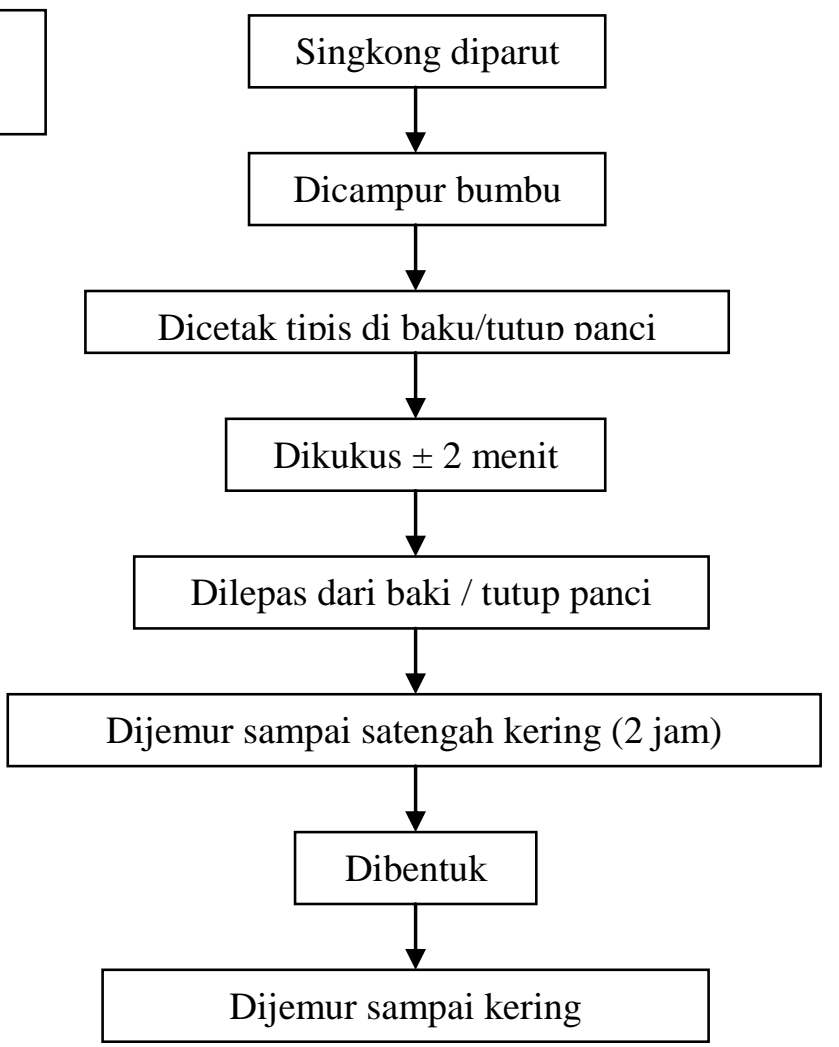

Gambar 2 Cara membuat kicimpring 


\section{CARA MEMBUAT DENDENG DAUN SINGKONG}

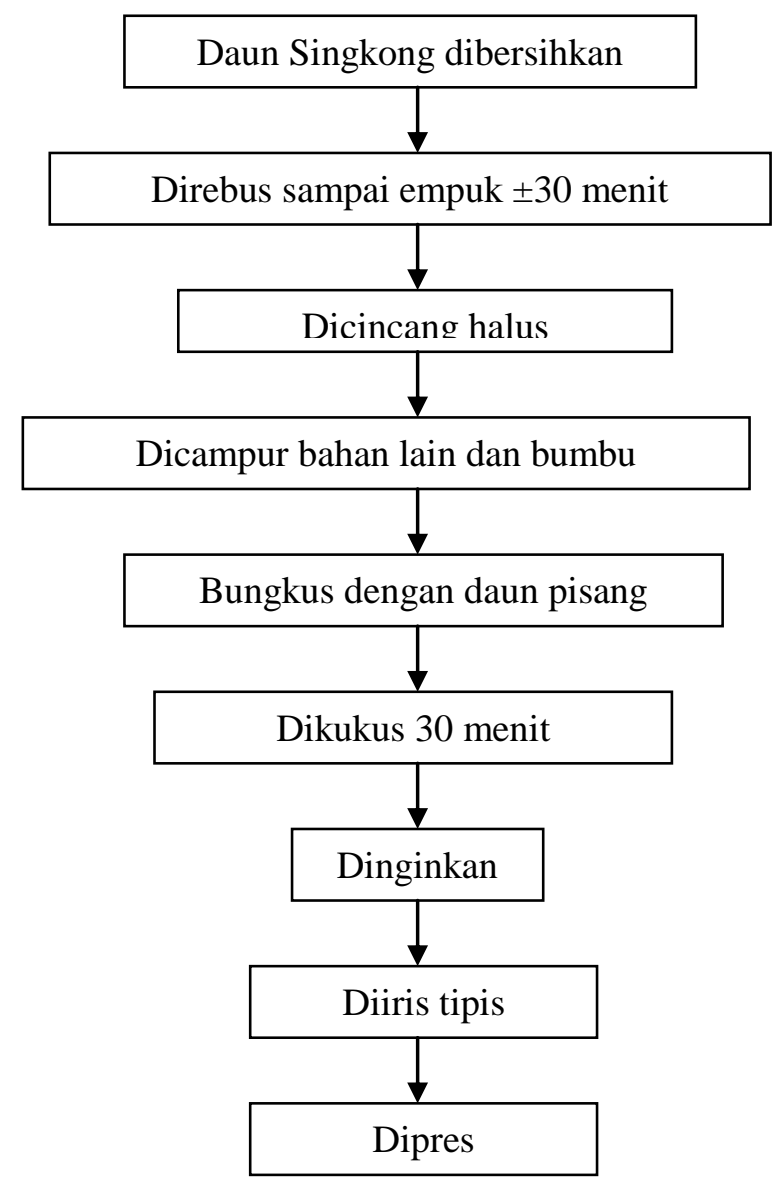

Gambar 3 Cara membuat dendeng daun singkong

Setelah pelatihan, dua kelompok pengrajin dibekali modal masing-masing sebesar Rp. 250.000,00 untuk mengembangkan kreativitas pengrajin dalam mengolah makanan berbasis singkong. Kegiatan ini merupakan tahapan dalam pameran menu hasil kreativitas pengrajin.

\section{Pameran Hasil Pengembangan Produk}

Kegiatan ini diawali dengan lomba membuat makanan olahan dari singkong. Terdapat 9 jenis kicimpring, 10 jenis dendeng, dan mie singkong hasil kreativitas peserta. Produk yang dilatihkan terdiri dari mie singkong, kicimpring belut, dan dendeng daun singkong. Setelah kegiatan pelatihan, produk berkembang dari 3 resep menjadi 20 resep. Produk tersebut terdiri kicimpring telur, kicimpring bandeng, kicimpring ikan nila, kicimpring ikan tongkol, kicimpring terasi udang, kicimpring tempe, kicimpring rebon original, kicimpring jengkol, dan kicimpring rebon pedas. Produk dendeng daun singkong terdiri dari dendeng daun singkong pedas, dendeng daun singkong manis, dendeng daun singkong gurih, dendeng daun singkong manis pedas, dendeng labu siam, dendeng bayam, dendeng jantung pisang, dendeng daun katuk, dendeng genjer, dan dendeng kangkung. Selain itu juga membuat mie singkong.

Dalam lomba, aspek yang dinilai meliputi aspek organoleptik (rasa, tekstur, aroma dan warna), penampilan produk, harga produk, kedaruratan, dan kebaruan produk (kreatifitas/inovasi) dengan juri meliputi Kepala Desa, Ketua Tim Penggerak PKK Desa, Ahli Gizi Puskesmas Salawu, dan 2 Dosen Gizi. Kegiatan Pameran berhasil dihadiri sebanyak 28 
orang meliputi unsur Puskesmas, ketua PKK Desa sukarasa, Kepala Desa Sukarasa dan pamong desa dan para peserta pelatihan, dan tim pengabmas.

\section{Penyusunan Pedoman Makanan Olahan Singkong.}

Buku pedoman menu sudah hampir selesai dibuat. Buku ini berupa kumpulan resep aneka olahan singkong, khususnya kicimpring dan dendeng daun singkong. Namun, selain makanan olahan dari singkong terdapat juga beberapa resep yang memanfaatkan bahan lokal di lokasi, seperti dendeng jantung, dendeng katuk, dendeng bayam, dan dendeng kangkung. Buku Pedoman menu dengan judul buku "OLAHAN SINGKONG PENUH RASA ALA DESA SUKARASA" yang berisi: Gizi Seimbang Untuk Hidup Sehat Produktif, Singkong Potensi Unggul Dalam Terwujudnya Penganekaragaman Pangan Dan Ekonomi Kreatif Rakyat; 20 Resep Makanan Olahan Singkong.

\section{Monitoring dan Evaluasi}

Kegiatan ini dilaksanakan untuk melihat keberlanjutan kegiatan pelatihan penyusunan menu. Hasil monitoring dan evaluasi menunjukkan bahwa ada keberlanjutan pembuatan produk baik dendeng maupun kicimpring. Makanan yang terus diproduksi ada 8 jenis yaitu kecimpring jengkol, kecimpring terasi udang belado, kecimpring terasi udaang pedas, kecimpring jengkol, kecimpring ikan, kecimpring sampeu tidak pedas, dendeng daun sampeu manis pedas rasa jengkol, dendeng daun singkong manis pedas.

Beberapa sudah dijual di warung dengan harga Rp. 500,00 dan Rp. 1000,00. Sebagian lagi ada yang dijual ke Garut melalui saudaranya, yaitu dengan kemasan Rp. 5000,00. Namun, pengrajin terkendala dengan bahan utama yaitu singkong dan daunnya dikarenakan sedang musim kemarau sehingga mereka tidak banyak memproduksi. Selain itu, mereka juga belum memiliki strategi pemasaran yang bagus. Mereka baru bisa memasarkan ke sodaranya atau hanya sekitar kampung mereka saja.

Pembuatan mie tidak dilanjutkan karena terkendala dengan bahan pencampur, seperti CMC. Mereka kesulitan mendapatkan bahan tersebut di pasar dekat mereka tinggal. Tetapi pernah mencoba menggantinya dengan nutrigel namun, hasilnya tidak sebagus yang menggunakan CMC. Dengan alasan demikian kelompok ibu-ibu tersebut tidak melanjutkan produksinya.

Kendala utama yang dihadapi para pengrajin dalam pengembangan produk kuliner, adalah :Pemasaran produk, Ketersedian bahan baku singkong terutama pada saat musim kemarau, Keterampilan dalam mendesain dan memproduksi kemasan dan labeling, Modal untuk memproduksi produk kuliner dalam jumlah banyak yang berkesinambungan; dan peralatan produksi yang masih tradisional dan terbatas, termasuk peralatan pencetakan produk yang berorientasi konsumen/pasar

\section{SIMPULAN}

Kegiatan ini menghasilkan kelompok pengrajin sebanyak 9 orang yang mampu membuat makanan kudapan untuk darurat bencana. Produk berkembang dari 3 resep menjadi 20 resep. Keberlanjutan produksi terlihat dari makanan olahan yang terus diproduksi ada 8 jenis yaitu kecimpring jengkol, kecimpring terasi udang belado, kecimpring terasi udang pedas, kecimpring jengkol, kecimpring ikan, kecimpring singkong tidak pedas, dendeng daun singkong manis pedas rasa jengkol, dan dendeng daun singkong manis pedas. 


\section{DAFTAR PUSTAKA}

1. Fatoni Z. 2015. Dampak Bencana Terhadap Kesehatan. http://kependudukan.lipi.go.id/id/kajiankependudukan/kesehatan-masyarakat/222-dampak-bencana-terhadap-kesehatan-masyarakat.

2. Kementerian Kesehatan RI. 2012. Pedoman Kegiatan Gizi dalam Penanggulangan Bencana. Kementerian Kesehatan RI: Jakarta.

3. Larasati S. 2015. Eksperimen Pembuatan Mi Kering Tepung Terigu Substitusi Tepung Ubi Jalar Kuning Dengan Penambahan Tepung Temulawak. Jurusan Teknologi Jasa dan Produksi. Fakultas Teknik. Universitas Negeri Semarang.

4. Manurung MY. 2017. Gempa Tasikmalaya, Kepala Daerah Diminta Keluarkan SK Darurat. https://nasional.tempo.co/read/1043112/gempa-tasikmalaya-kepala-daerah-diminta-keluarkan-skdarurat.

5. UNHCR/UNICEF/WFP/WHO. 2003. Food and Nutrition Needs in Emergencies. The John Hopkins and Red Cross Red Crescent. 2008. Public Health Guide in Emergencies. $2^{\text {nd }}$ Edition. International Federation of Red Cross and Red Crescent Societies, Geneva.

6. The Sphere Project. 2011. The Sphere Handbook: Humanitarian Charter and Minimum Standards in Humanitarian Response. 